TEORIAS DA JUSTIÇA

\title{
Materialismo e Dialéticas sem Aufhebung: Adorno, leitor de Marx; Marx, leitor de Hegel
} Materialism and Dialectics without Aufhebung: Adorno's reading of Marx and Marx's reading of Hegel

Vladimir P. Safatle ${ }^{1}$

Resumo: Este artigo visa discutir os modelos de síntese pressupostos pela dialética negativa de Adorno através de aproximações de temáticas maiores da filosofia de Karl Marx. Isto nos permitirá qualificar melhor a natureza materialista da dialética negativa adorniana, abordando inclusive o impacto político de certas elaborações conceituais.

Palavras-chave: Síntese. Aufhebung. Dialética negativa. Marx, Hegel, Adorno. Materialismo.

Abstract: This article aims to discuss the models of synthesis presupposed by adornian negative dialectic. For it, we should evaluate the meaning of the close relations between Adorno and some themes from Karl Marx's philosophy. With this strategy in mind we can better qualify the materialistic nature of adornian negative dialectic, exposing through it the political impact of some conceptual productions.

Keywords: Synthesis. Aufhebung. Negative Dialectic. Marx, Adorno, Hegel. Materialism.

${ }^{1}$ Departamento de filosofia da USP < vsafatle@yahoo.com> 
Ce n'est point avec des idées qu'on fait des vers, C'est avec des mots. Stéphanne Mallarmé

A posteridade filosófica nos acostumou à ideia de que a dialética negativa adorniana seria uma espécie de dialética amputada do momento positivo-racional de síntese. Amputação resultante principalmente da pretensa liberação da negação determinada de sua função estruturadora no interior da noção hegeliana de totalidade. Pois, em Hegel, a negação determinada seria, ao menos segundo esta perspectiva, o movimento de constituição de relações entre os conteúdos da experiência tendo em vista a produção de uma totalidade acessível ao saber da consciência. Ao passar de um conteúdo da experiência a outro através de negações determinadas, compreendendo com isto que o resultado das negações não é a anulação do conteúdo anterior mas a revelação de como ambos os conteúdos estavam em profunda relação de interdependência, a consciência teria as condições de fazer a experiência de como a determinação de um conteúdo só é completamente possível através da atualização da rede de negações que o define. Ou seja, ela compreenderia o verdadeiro sentido do adágio spinozista: Omni determinatio est negatio ${ }^{2}$. Tal atualização da rede de negações que determinam os conteúdos da experiência seria exatamente o que Hegel compreenderia por posição da totalidade do saber. Uma posição que, por sua vez, determinaria a negatividade como astúcia que visa mostrar o caráter limitado dos momentos parciais da experiência, pois tais parcialidades seriam superadas pelo desvelamento da funcionalidade de cada momento em uma visão acessível do todo.

Já a dialética negativa adorniana, enquanto "prática ad hoc da negação determinada"3, acabaria na aporia de uma crítica totalizante da razão incapaz de se orientar a partir de um horizonte concreto de reconciliação, beirando assim o niilismo desenfreado ${ }^{4}$. Isto quando ela não for acusada de simplesmente não ser dialética. Basta lembrarmos, a este respeito, do comentário de Robert Pippin: “a 'dialética negativa' simplesmente não é dialética, mas uma filosofia da finitude e uma demanda para o reconhecimento de tal finitude. O 'não-idêntico'

\footnotetext{
${ }^{2}$ Comentadores como Robert Brandom compreenderam claramente este ponto, mas devido a uma apreensão não-dialética da negação determinada como simples relação de oposição, eles tendem a ver, na força determinante da negação hegeliana, apenas uma figura mais rebuscada da incompatibilidade material (Ver BRANDOM, Robert. Tales of the mighty death, Harvard University Press, 2002, p. 180)

${ }^{3}$ HABERMAS, Jürgen. O discurso filosófico da modernidade, São Paulo: Martins Fontes, 2002, p. 183

${ }^{4}$ Este é o sentido de afirmações de Habermas, a respeito de Adorno, como: "A suspeita nos confrontos da ideologia torna-se total [...] Esta não se volta somente contra a função irracional dos ideais burgueses, mas também contra o próprio potencial de racionalidade da cultura burguesa".
} 
desempenha um papel retórico estranhamente semelhante à identificação kantiana da Ding an sich contra os idealistas posteriores" 5 . A referência a Kant não é extemporânea porque, aparentemente, seria possível ver a dialética transcendental como uma espécie de dialética negativa, já que ela também é uma crítica da totalidade, mas através da exposição das ilusões produzidas pelo uso transcendente das ideias transcendentais. $O$ que talvez nos explique porque esta leitura da dialética negativa como uma filosofia da finitude de ares kantianos será encontrada em várias tradições de interpretação. Lembremos, por exemplo, de Alain Badiou, para quem: "o que Adorno retém de Kant é a irredutibilidade da experiência, a impossibilidade de dissolver a experiência na pura atividade do conceito. Subsiste um elemento totalmente irredutível de limitação passiva, exatamente como em Kant a passividade, que é a prática do sensível, é irredutível"6.

Neste artigo, eu gostaria de questionar tais leituras mostrando como elas erram de alvo a respeito da função da negatividade em Adorno, com sua figura privilegiada expressa no conceito de "não-idêntico". Para tanto, gostaria de lembrar que uma dialética cujo momento positivo-racional não pode ser pensado a partir da noção de Aufhebung e que se vê como uma "antissistema" não significa, necessariamente, uma dialética que abandonou todas as aspirações de síntese e totalidade. A crítica de Adorno ao positivismo e à sua ausência de referência a uma perspectiva valorativa produzida pela possibilidade de realização de uma totalidade verdadeira já deveria nos colocar em guarda contra toda tendência a falar em uma dialética sem síntese ${ }^{7}$.

Mas é fato que a síntese em Adorno obedece a princípios não evidentes como, por exemplo, estes que encontramos na exigência de "liberar a dialética de sua essência afirmativa sem perder nada de sua determinidade" 8 . Notemos como estamos aqui diante de um problema ligado a modalidades de síntese, já que o problema da determinação é, necessariamente, vinculado ao problema dos modos de reconciliação entre sentido e experiência. Mas, afinal, o que pode ser uma determinação

\footnotetext{
${ }^{5}$ PIPPIN, Robert. "Negative ethics: Adorno on the falsehood of bourgeois life" In: The persistence of subjectivity: on the Kantian aftermath, Cambridge University Press, 2005, p. 116.

${ }^{6}$ BADIOU, Alain. " La dialectique negative d'Adorno "In : Cinq leçons sur le 'cas' Wagner, Paris : Nous, 2010, p. 65.

${ }^{7}$ Lembremos do que diz Adorno: “A mediação dialética do universal e do particular não autoriza a teoria que opta pelo particular a, de maneira ultrarrápida, tratar o universal como uma bolha de sabão. Pois nesse caso a teoria não poderia apreender nem o predomínio pernicioso do universal naquilo que se acha estabelecido, nem a ideia de uma situação que conduzindo os indivíduos ao que lhes é próprio, privaria o universal de sua má particularidade" (ADORNO, Theodor. Dialética negativa, Rio de Janeiro: Jorge Zahar, 2009, p. 170/ Negative Dialektik, Frankfurt: Suhrkamp, 1973, p. 200) [as traduções da Dialética Negativa, quando necessário, serão corrigidas ou traduzidas diretamente do original].

${ }^{8}$ ADORNO, Theodor. Dialética negativa, op. cit., p. 7/ Negative Dialektik, p. 9.
} 
que conserva sua capacidade de distinguir, de definir o sentido e de expressar a existência do que ela determina sem, com isto, submeter a experiência à adequação a um campo articulado de normatividades atualmente afirmadas, ou seja, ao campo de normatividades que podem ser compreendidas como afirmações a partir da gramática atualmente reguladora? Em suma, o que pode afinal significar "determinar sem afirmar"? Seria determinar sem dizer o que a coisa é, convidando-nos assim a uma aporia negativista, ou seria determinar, mas impedindo que a coisa seja dita sem que antes a linguagem atual e sua práxis entrem em colapso, insistindo que a coisa porta uma experiência que desestabiliza o campo atual de condições prévias a toda experiência compreendida como possível? Pois se assim for, a dialética negativa não poderia ser vista como um certo culto do paradoxo e das aporias produzida pela retração dos horizontes de reconciliação. Ao contrário, ela seria a condição necessária para a reorientação de toda práxis com potencial efetivo de transformação.

Tenhamos tal problema em mente ao tentarmos interpretar definições de dialética como esta que encontramos logo nas primeiras páginas do livro Dialética Negativa: "Seu nome não diz inicialmente senão que os objetos não se dissolvem em seus conceitos, que esses conceitos entram por fim em contradição com a norma tradicional de adaequatio" ${ }^{9}$. Fica evidente que esta dialética reduzida a seu núcleo de crítica imanente obriga o pensamento a apreender a forma com que os objetos realizam seus próprios conceitos exatamente no momento em que esses mesmos objetos não se adequam mais a seus próprios conceitos. Longe de um simples culto do paradoxo, temos aqui a definição da dialética como a compreensão de que a contradição entre o objeto e seu conceito é a produção de um processo que só pode ser apreendido em seu real sentido à condição de abandonarmos as expectativas de adequação próprias à gramática da representação.

Isto poderia parecer impensável. No entanto, não seria tal definição uma maneira de dizer que os objetos podem criticar seus conceitos, que os processos podem criticar suas normas, não hipostasiando o aconceitual ou o anormativo, mas salvando algo que destrói as primeiras expectativas normativas dos conceitos, ou seja, algo que destrói aquilo que um dia Hegel chamou de "representações naturais"? Se assim for, a dialética poderá aparecer como o movimento que obriga os conceitos e liberarem uma potencialidade, presa no interior das suas disposições normativas iniciais, que só pode ser pensado para além da situação atual. Desta forma, os conceitos só se realizam destruindo as situações que eles pareciam inicialmente normatizar e assegurar.

\footnotetext{
${ }^{9}$ Idem, p. 12/ ND, p. 17.
} 
Neste sentido, um exemplo paradigmático do movimento dialético tentado por Adorno será fornecido pela seguinte passagem da Dialética Negativa:

\begin{abstract}
O juízo de que alguém é um homem livre refere-se, pensado de maneira enfática, ao conceito de liberdade. Esse conceito contudo é, por sua vez, mais do que aquilo que é predicado deste homem, tanto quanto todo homem, por meio de outras determinações, é mais do que o conceito de sua liberdade. Seu conceito não diz apenas que podemos aplicá-lo a todos os homens singulares definidos como livres. Nele, encontra-se a ideia de um estado no qual os singulares teriam qualidades que não poderiam ser atribuídas aqui e hoje a ninguém. Celebrar alguém como livre tem sua especificidade no sous-entendu de que lhe é atribuído algo impossível porque esse algo se manifesta nele; esse elemento que ao mesmo tempo salta aos olhos e é secreto anima todo juízo identificador que de alguma maneira é válido. O conceito de liberdade fica aquém de si mesmo no momento em que é aplicado empiricamente. Ele mesmo deixa de ser então o que ele diz ${ }^{10}$.
\end{abstract}

Essa passagem é exemplar a respeito do que Adorno entende por dialética negativa e por processo dialético. Liberdade não é algo que se predica de um sujeito sem que tal predicação não acabe por nos levar a um processo contraditório com a situação atual e suas relações de reconhecimento e trabalho, a uma desarticulação do próprio campo dos predicados, a um estado impossível de ser determinado a partir das potencialidades de determinação vigentes no aqui e agora. Daí a necessidade de afirmar que o conceito de liberdade é "mais do que aquilo que é predicado deste homem". Por isto, determinar enfaticamente um homem como livre é, ao mesmo tempo, atribuir-lhe algo que destrói o conceito de liberdade tal como ele atualmente determina e identifica em sua potencialidade afirmativa.

Adorno é claro a respeito da desestabilização normativa produzida pela relação de síntese entre sujeito e predicado quando associamos "homem" a "livre". Tal desestabilização normativa é fruto de uma crítica social às condições que reinam "aqui e hoje". O que nos explica porque celebrar alguém como livre é apelar àquilo que não é sequer possibilidade de um estado atual, ou seja, que não é normatividade realizada sequer como possibilidade da situação atual, mas que é impossibilidade que coloca o atual em contradição. Celebrar alguém como livre é leva-lo a se confrontar com um "impossível".

No entanto, notemos como este "impossível" não é um não-realizável, uma mera determinação aporética. Impossível é apenas aquilo que, a partir da perspectiva das possibilidades reguladas pela situação atual, não pode se realizar. Neste sentido, o conceito de liberdade precisa ficar

${ }^{10}$ Idem, p. 131/ ND, p. 154. 
aquém de si mesmo quando aplicado por esta ser a forma de colocar a situação atual em movimento sem, com isto, reiterar mais uma vez aquilo que se reduziu a ser apenas um possível das normatividades atuais. Notase aqui, de forma clara e distinta, a função política da negatividade, assim como o empuxo da contradição em direção à atividade.

Há várias maneiras de expor a natureza deste movimento, mas eu gostaria de escolher uma via pouco explorada, a saber, mostrar como a dialética negativa adorniana reatualiza motivos próprios às críticas feitas por Marx a Hegel. Da mesma forma, gostaria de mostrar como mesmo algumas das principais estratégias de Adorno em sua reinvenção da dialética (como a crítica da estrutura sintética da consciência-de-si, a dialética como lógica da desintegração, o primado do objeto e a insistência em um "momento somático" no pensamento dialético) são reverberações de estratégias próprias à dialética marxista, muito claramente presentes principalmente nos textos do jovem Marx (referência maior para a primeira geração da Escola de Frankfurt). Esta aproximação entre Marx e Adorno será uma maneira de colocar em outras bases o problema da práxis produzida pela dialética negativa.

Insistamos inicialmente que tal proximidade não deveria nos surpreender já que, antes de Adorno, a dialética de Marx colocava-se claramente como uma "dialética sem Aufhebung". À sua maneira, Marx também visava liberar-se da natureza afirmativa da dialética hegeliana sem perder nada em determinação, ou seja, se quisermos, à sua maneira a dialética de Marx também era negativa pois suas formas de síntese não implicam na suspensão da força desestabilizadora da negatividade em prol a assunção de um horizonte teleológico ${ }^{11}$. Tal como Adorno, ele também partia da constatação de que: "nenhuma das reconciliações sustentadas pelo idealismo absoluto (todas as outras permaneceram inconsequentes) desde a reconciliação lógica até a histórico-política, se mostrou convincente" ${ }^{12}$. Lembrar esta possibilidade é uma forma de criticar certas leituras correntes que procuram reduzir o potencial de transformação da dialética negativa, desconhecendo deliberadamente como ela visa, ao contrário, descrever a função da negatividade nas dinâmicas de transformação das determinações.

De fato, há de se lembrar de como a filosofia contemporânea é marcada por um equívoco fundamental a respeito do que é a negatividade. A

\footnotetext{
${ }^{11} \mathrm{O}$ que não poderia ser diferente para alguém que afirma, por exemplo: "O comunismo não é, para nós, um estado/situação (Zustand) que deve ser estabelecido, um ideal ao qual a realidade deve se sujeitar. Nós chamamos de comunismo o movimento real que supera o estado atual" (MARX, Karl e ENGELS, Friedrich. Die deutsche Ideologie In: Gesammelte Werke, Colônia: Anaconda, 2016, p. 54). Ou seja, comunismo não é o nome de uma situação a ser implementada, de um ideal utópico a ser realizado. Ele é o nome de um tipo específico de movimento, um tipo de insurgência capaz de abrir a situação atual ao que ela só pode determinar como contradição profunda, produzindo assim o aniquilamento do modo de vida atualmente reproduzido.

${ }^{12}$ ADORNO, Theodor. Idem, p. 14.
} 
leitura moral da negatividade como a força niilista de ressentimento contra o acontecimento é ruim por confundir crítica e resignação ${ }^{13}$. Já a tentativa de reduzir a negatividade a uma figura do escapismo aristocrático (como vemos na tradição que se abre com Jürgen Habermas) só poderia aparecer em um país, como a Alemanha contemporânea, marcado pelo vínculo compulsivo a um modelo de gestão social, no caso, o Estado do bem-estar social, que só pode sobreviver por eliminar todo horizonte de transformação real. Nenhuma destas duas leituras faz jus ao que pode a negatividade. Elas não são capazes de pensar o que significa uma atividade que tem sua força motriz na capacidade de negar. Pois a negatividade é uma forma de não esmagar a possibilidade no interior das figuras disponíveis das determinações presentes. De certa forma, há sempre algo de não realizado no que se realiza e esta franja do indeterminado que corrói toda determinação é o lugar no qual a possibilidade se apresenta como negatividade.

\section{Conservar o que deveria ser dissolvido}

Retomemos então a crítica de Marx à noção hegeliana de Aufhebung a fim de melhor compreender este ponto. Uma das múltiplas maneiras de discutir a crítica de Marx à dialética hegeliana é partindo deste seguinte trecho do início da Fenomenologia do Espírito que bem descreve o conceito hegeliano de saber absoluto e, por consequência, seu movimento de Aufhebung.

A tarefa de conduzir o indivíduo, deste seu ponto de vista inculto (ungebildeten - não formado) até o saber, devia ser apreendida em seu sentido universal, levando em conta o indivíduo universal, o espírito do mundo (Weltgeist) em sua formação. No que concerne à relação entre ambos, em cada momento do indivíduo universal se mostra o modo como [o espírito do mundo] obtém sua forma (Form) concreta e sua figuração (Gestaltung) própria. Mas o indivíduo particular é o espírito incompleto, uma figura (Gestalt) concreta cuja existência (Dasein) complta conhece uma só determinidade, enquanto outras determinidades ali só estão presentes como traços rasurados. (...) O indivíduo cuja substância é o espírito situado no mais alto, percorre esse passado da mesma maneira como quem se apresta a adquirir uma ciência superior, percorre os conhecimentos preparatórios que há muito tem dentro de si, para fazer seu conteúdo presente; evoca de novo sua rememoração (Erinnerung), sem no entanto ter aí seu interesse ou demorar-se neles. Cada singular deve também percorrer os degraus de formação do espírito universal, mas como figuras já depositadas pelo espírito, como níveis de um caminho já preparado e aplainado. (...) Essa existência passada já é propriedade adquirida do espírito universal (...) A formação do indivíduo nesta consideração consiste em adquirir o que

\footnotetext{
${ }^{13}$ Ver DELEUZE, Gilles. Nietzsche et la philosophie, Paris: PUF, 1962.
} 
lhe é apresentado, consumindo em si mesmo sua natureza inorgânica e tomando posse dela para $\mathrm{si}^{14}$.

Uma leitura tradicional (que não é a única possível ${ }^{15}$ ) diria que caberia ao indivíduo apenas rememorar este processo, estas "plataformas de um caminho já aplainado" apropriando-se de um Espírito que age no indivíduo, mas à sua revelia. Ele deveria "adquirir o que lhe é apresentado" confirmando o que aparece na efetividade como uma necessidade ainda não reconhecida. Pois a verdadeira experiência seria, no fundo (e este é o ponto fundamental), uma rememoração de formas já trabalhas pelo desenvolvimento histórico do Espírito. Neste momento, o indivíduo deixaria de orientar seu agir e seu julgamento como consciência individual para orientar-se como encarnação de um Espírito do mundo que vê sua ação como posição de uma história universal que funciona como elemento privilegiado de mediação. O indivíduo singular transformar-se-ia em consciência do espírito de seu tempo, adquirindo a perspectiva da totalidade própria ao absoluto. O que só poderia significar uma absolutização do sujeito que deixa de ser apenas Eu individual para ser aquele capaz de narrar a história universal e ocupar sua perspectiva privilegiada de avaliação. $\mathrm{E}$ aí que chegaríamos se levássemos ao pé da letra afirmações aquivocadas de comentadores como Jean Hyppolite, para quem: "A história do mundo se realizou; é preciso somente que o indivíduo singular a reencontre em si mesmo (...) A Fenomenologia é o desenvolvimento concreto e explícito da cultura do indivíduo, a elevação de seu eu finito ao eu absoluto, mas essa elevação não é possível senão ao utilizar os momento da história do mundo que são imanentes a essa consciência individual" ${ }^{16}$. Enfim, tudo se passaria como se a experiência da consciência fosse rememoração e esta, por sua vez, fosse historicização capaz de nos levar a compreender como o passado determina nosso agir, constitui a racionalidade de nossas instituições e nossos padrões atuais de racionalidade. Como se a palavra que traz o Saber Absoluto fosse: "No fundo, eu sempre soube".

Seria possível criticar esta forma "quietista" de compreender a rememoração hegeliana, eu mesmo já fiz isto em outra ocasião. Este quietismo vê a filosofia como uma certa terapéutica conservadora contra a ilusão de que deveríamos insistir no não realizado ${ }^{17}$. É certo, no entanto,

\footnotetext{
${ }^{14}$ HEGEL, G.W.F. Phänomenologie des Geistes, Hamburgo: Feliz Meiner, 1988, pp. 22-23

${ }^{15} \mathrm{Eu}$ mesmo forneci uma leitura distinta deste trecho em SAFATLE, Vladimir. O circuito dos afetos: corpos políticos, desamparo e o fim do indivíduo, Belo Horizonte: Autêntica, 2016.

${ }^{16}$ HIPPOLYTE, Jean. Gênese e estrutura da Fenomenologia do Espírito, São Paulo: Discurso Editorial, 2004, pp. 56-57.

${ }^{17}$ Ver, por exemplo, MCDOWELL, John. Having the world in view: essays on Sellars, Kant and Hegel, Harvard University Press, 2009. Uma versão de certa leitura quietista da dialética hegeliana pode ser encontrada em HÖSLE, Vittorio. O sistema de Hegel: 0 idealismo da subjetividade e o problema da intersubjetividade, Belo Horizonte: Loyola, 2007.
} 
que uma certa crítica do pretenso quietismo hegeliano orienta em larga medida a leitura de Marx. A seu ver, a submissão hegeliana da experiência à rememoração é a prova maior de que as conciliações se dão em Hegel como formas astutas de confirmação da efetividade, de cura da crença de que a teoria deve descrever a necessidade de uma transformação ainda não ocorrida. O retorno a si pressuposto pela experiência hegeliana seria apenas a elevação da efetividade à condição de objeto pensado de forma adequada e esta elevação seria a verdadeira forma da reconciliação e da síntese.

Este é um topos repetido por Marx de forma insistente: Hegel reinstauraria a existência no ser-pensado, transformando com isto o mundo dos objetos em abstração do pensamento. Daí afirmações como: "o pensar enquanto pensar finge imediatamente ser o outro de si mesmo"18. Marx é ainda mais claro ao afirmar que não é o caráter determinado do objeto que aparece a Hegel como fator de alienação mas, na verdade, o caráter objetivo em geral. A objetividade do objeto deve se dissolver na abstração de uma consciência-de-si cujo saber, cuja capacidade de percorrer os degraus da formação cultural do espírito universal é seu único ato. $O$ objeto se revelaria assim apenas como a aparência de um objeto, como mero projeção do saber da consciência e suas teias de rememoração:

O objeto é por isso mesmo um negativo que supera a si mesmo, uma nulidade (Nichtigkeit). Essa nulidade em si não tem para a consciência apenas uma significação negativa, mas positiva, pois aquela nulidade do objeto é justamente a auto-confirmação da não-objetividade de sua própria abstração ${ }^{19}$.

Mas notemos como o movimento aqui é duplo. Não é apenas o pensar que determina as possibilidades de existência em um idealismo que parece tender a confundir percepção com mero delírio. É a existência que limita um pensar que aparece agora sob a figura privilegiada da rememoração do já estabelecido, e este é o ponto que deve ser salientado. Isto fica claro na crítica que Marx faz à concepção hegeliana de Aufhebung. Através da Aufhebung, dirá Marx, tudo o que é superado continua existindo sob a forma de momentos necessários da auto-confirmação do Espírito. Ou seja, o pensar é apenas a reconfirmação da contingência da existência sob a forma da necessidade:

Assim, por exemplo, na filosofia do direito de Hegel, o direito privado superado $=$ moral, a moral superada $=$ família, a família superada $=$ sociedade civil, a sociedade civil superada é igual ao Estado, o Estado superado = história mundial. $\mathrm{Na}$ realidade, continuam subsistindo

\footnotetext{
${ }^{18}$ MARX, Karl. Ökonomisch-philosophische Manuskripte, Frankfurt: Suhrkamp, 2015, p. 158.

${ }^{19}$ Idem, p. 158.
} 
direito privado, moral, família, sociedade civil, Estado etc.; apenas se tornaram momentos, existências e modos de presença (Daseinsweisen) do homem que não valem isoladamente, se dissolvem e se engendram reciprocamente etc., momentos do movimento ${ }^{20}$.

O mínimo que se pode dizer é que tal crítica é astuta. Marx está a dizer que esta superação hegeliana, esta negação que conserva, não é outra coisa senão a forma possível de reconciliação própria a uma consciência teórica que deixa os objetos permanecerem na efetividade ao invés de produzir uma ação capaz de negar efetivamente a configuração concreta dos mesmos. Direito privado, moral, família permanecem na efetividade, mas sob a forma de espectros cuja realidade é fornecida pela sua remissão possível ao conceito. Moral, família, sociedade civil, direito privado não terão realidade em si, embora permaneçam na efetividade. Eles serão apenas momentos de efetivação da ideia, eles serão as figurações incompletas da ideia e sua realidade será vista apenas sob o signo da incompletude. Mas, e este é o ponto mais importante, tal incompletude não levará a uma modificação na ordem do existente. No máximo, ela levará a uma modificação no modo de interpretação do existente, mas tal modificação da interpretação não produziria uma modificação nas condições efetivas de reprodução das realidades anteriormente criticadas.

Lembremos, por exemplo, da famosa frase de Hegel: "o que é racional é real e o que é real é racional" (Was vernünftig ist, das ist wirklich; und was wirklich ist, das ist vernünftig) ${ }^{21}$. Há duas formas de ler esta frase canônica. Primeiro, insistindo na dissociação necessária entre Wirklichkeit e Realität, o que equivaleria afirmar que o real no interior do qual a filosofia encontra sua racionalidade não se confunde com o curso atual do mundo. Haveria uma latência da existência através da qual passa um real que não se esgota nas determinações postas da realidade atual. É a capacidade de reconhecer tal real que permitiria à filosofia compreender o que é racional.

Segundo, podemos lê-la afirmando que apenas o que se conforma à normatividade previamente determinada da razão pode aspirar realidade. No entanto, se tais normatividades tem uma semelhança insidiosa com a realidade atualmente posta é porque, ao menos neste caso, o real se confundiria com o atualmente existente, o que implicaria na tentativa de racionalizar e fazer passar por absolutamente necessário aquilo que era fruto da contingência do desenvolvimento histórico. É esta segunda leitura que guia o jovem Marx. Tal crítica está posta claramente no seguinte exemplo referente à teoria hegeliana do Estado:

\footnotetext{
${ }^{20}$ Idem, p. 160.

${ }^{21}$ HEGEL, G.W.F. Grundlinien der Philosophie des Rechts, Frankfurt: Suhrkamp, p. 24.
} 
A essência das determinações do Estado não consiste em que se possam ser consideradas como determinações do Estado, mas sim como determinações lógico-metafísicas em sua forma mais abstrata. $O$ verdadeiro interesse não é a filosofia do direito, mas a lógica. O trabalho filosófico não consiste em que o pensamento se concretize nas determinações políticas, mas em que as determinações políticas existentes se volatizem no pensamento abstrato ${ }^{22}$.

Notemos mais uma vez a duplicidade da crítica. Primeiro, Marx afirma que interessa a Hegel apenas a maneira com que a lógica submete a filosofia do direito, como o existente se volatiza no pensamento conceitual. Assim, por exemplo: "não se trata de desenvolver a ideia determinada da constituição política, mas de dar à constituição política uma relação com a Ideia abstrata, de dispô-la como um membro de sua biografia (da Ideia): uma clara mistificação" ${ }^{23}$. Mistificação significa aqui uma certa inversão na qual a consequência passa à condição de causa, o predicado passa à condição de sujeito, o contingente esconde sua condição de contingente e se coloca sob a forma imediata do necessário.

Ora, mas o verdadeiro problema não está apenas no fato de partirmos da ideia para depois medirmos a realidade a partir de sua adequação àquilo que se colocou como ontologicamente necessário. De fato, com isto eliminamos a possibilidade de compreender como singularidades se desenvolvem em processos temporais marcados por contingências que se afirmam enquanto tais. Mas há ainda um segundo movimento nesta relação de subsunção entre conceito e objeto. Pois percebamos como, se as determinações lógico-metafísicas expressassem o que ainda não se configurou como determinações do Estado, então estaríamos diante de uma filosofia capaz de abalar o sistema de justificação do mundo institucional. Neste sentido, a Ideia guardaria a força do que ainda não se realizou, garantindo a perpetuação de um movimento de transformação da efetividade.

No entanto, não é isto que ocorre na dialética hegeliana, ao menos segundo o jovem Marx. Pois a Ideia é produzida à semelhança da efetividade, as determinações do Estado atual são mistificadas como expressão da necessidade do Espírito e postas como determinações absolutas. Ou seja, não é apenas a ideia que subordina a existência. $A$ existência define previamente as potencialidades internas à própria Ideia. A existência aparece assim como o terreno insuperável da necessidade. Somos até tentados a dizer: segundo Marx o problema com a filosofia hegeliana não é sua demasiada abstração, mas seu demasiado realismo.

Mas notemos uma pressuposição fundamental aqui. Há em todos esses caso a pressuposição de uma certa inefetividade do que chamamos anteriormente de "mera modificação no modo de interpretação". No

\footnotetext{
${ }^{22}$ MARX, Karl. Crítica da filosofia do direito de Hegel. São Paulo: Boitempo, p. 38.

${ }^{23}$ Idem, p. 36.
} 
entanto, esta pressuposição deveria ser contextualizada em seu horizonte histórico. Afinal, em todo e qualquer momento histórico, mudar a forma de interpretar é apenas um movimento inefetivo ou pode equivaler a uma reconfiguração das próprias condições de possibilidade da experiência? Esta é uma pergunta fundamental pois há de se questionar se haveria situações nas quais a assunção de outra interpretação já equivale a uma mudança na potencialidades próprias a práxis, pois equivaleria a uma redescrição que abre novas possibilidades de ação, que reconfigura as condições de possibilidade da ação. Se estas questões não aparecem como plausíveis a Marx (o que lhe levaria a rever sua leitura quietista de Hegel) é porque seu contexto histórico está assombrado por uma forma de paralisia a respeito da qual ele acredita que a dialética hegeliana nos cega. Ou seja, trata-se de uma avaliação histórico-contextual que devemos especificar.

\section{A história e suas paralisias}

Tentemos então desenvolver melhor este ponto a respeito do contexto histórico da crítica de Marx. Lembremos, mais uma vez, como Marx insiste que aqueles interessados em uma dialética como força de transformação, precisarão desenvolver uma dialética sem Aufhebung. Como vimos anteriormente, Marx afirma que a dialética hegeliana nos levaria apenas a uma transcendência negativa que se incarna na definição da essência como ser-pensado. Ou seja, esta superação hegeliana seria, ao mesmo tempo, esvaziamento, desrealização das relações concretas, pois seria exposição de tais relações em sua parcialidade e inverdade. Mas ela é também confirmação de uma existência reduzida à condição de alegoria, de aparência, já que a superação não tem força para produzir nenhuma outra realidade. No máximo, ela pode ressignificá-las. Mas como a ideia é mera força da negatividade, a reinscrição produzida pela consciência é apenas a elevação dos existentes à condição de encarnações de negações. Criação de um mundo não muito diferente daquele que Marx compreende ao encarar a realidade alemã do século XIX e de seus sistemas complexos de compensação à paralisia social e a seu desenvolvimento retardatário.

Neste ponto, devemos lembrar da importância do diagnóstico de época a respeito do atraso da situação alemã e sua dificuldade de transformação social que fundamenta a crítica marxista a Hegel. O jovem Marx insistia como depois da crítica iluminista à religião, cabia à filosofia desmascarar a autoalienação humana em suas formas não-sagradas, ligadas às modalidades de reprodução material da vida. Como ele dirá, "a crítica do céu se transforma na crítica da terra, a crítica da religião na 
crítica do direito, a crítica da teologia na crítica da política"24. Forma de radicalizar a proposição kantiana a respeito da época moderna como a época da crítica.

No entanto, na Alemanha retardatária em relação aos processos de inserção nas dinâmicas do liberalismo econômico e da sociedade burguesa do livre-mercado, assombrada pelo descompasso entre efetividade nacional e ideia em compasso de igualdade com outras nações centrais, isto não poderia ocorrer. No caso alemão, a filosofia não teria passado à crítica da terra, ou seja, ela não teria gerado uma revolução como no caso francês no qual a filosofia iluminista será uma das bases do processo revolucionário. Na verdade, ela terá servido à construção de uma mitologia cuja verdadeira função era justificar intelectualmente a natureza do atraso social, bloqueando assim a imaginação política ${ }^{25}$. Ou seja, teríamos um caso exemplar do que, entre nós, chamaríamos de "ideias fora de lugar". Os alemães seriam contemporâneos filosóficos do presente sem serem contemporâneos históricos da realidade atual ${ }^{26}$. Daí porque Marx dirá que, enquanto as outras nações do mundo viveram sua préhistória na mitologia, a Alemanha teria vivido sua pré-história exatamente na filosofia, que seria o verdadeiro nome da mitologia alemã. Assim, por exemplo, através da filosofia alemã do direito e do Estado, a Alemanha procurou ligar sua história mitológica às condições presentes. Pois os alemães teriam simplesmente pensado o que os outros fizeram, sendo por isto obrigados a acertar o descompasso entre ideia e efetividade a partir de conciliações meramente formais, participando, por exemplo, de todas as ilusões do regime constitucional sem compartilhar suas realidades. Por isto, Marx tem de insistir que

todas as formas e todos os produtos da consciência não serão destruídos por obra da crítica espiritual (...) mas tão somente podem ser dissolvidas com a derrocada prática das relações sociais reais, das quais emanam essas quimeras idealistas ${ }^{27}$.

É este diagnóstico de época que leva Marx a compreender a negatividade hegeliana simplesmente como força de abstração cuja

${ }^{24}$ MARX, Karl. Zur Kritik der Hegelschen Rechtphilosophie. Einleitung, In: Gesammelte Werke, Colônia: Anaconda, 2016, p. 12.

${ }^{25}$ Lembremos, por exemplo, de uma afirmação como: "A situação da Alemanha no final do século passado espelha-se completamente na Crítica da razão prática de Kant. Enquanto a burguesia francesa se impulsionou, através da mais colossal das revoluções que a história jamais conheceu, ao poder, e conquistou o continente europeu, enquanto a burguesia inglesa revolucionou a indústria e submeteu comercialmente a Índia e todo o resto do mundo, os impotentes burgueses alemães alcançaram apenas chegar à 'boa vontade'" (MARX, Karl e ENGELS, Friedrich. A ideologia alemã, Rio de Janeiro: Civilização Brasileira, 2007, p. 219).

${ }^{26}$ Para um estudo detalhado deste ponto, ver ARANTES, Paulo. Ressentimento da dialética, São Paulo: Paz e Terra, 1996.

${ }^{27}$ MARX, Karl e ENGELS, Friedrich. $A$ ideologia alemã, op. cit., p. 62. 
função estaria ligada a uma dinâmica compensatória às paralisias sociais. Ela é a maneira de determinações abstratas se fixarem como verdadeiro conteúdo das efetividades postas, conservando efetividades postas em crise. Neste sentido, ela é uma forma de criação de abstrações concretas. Parece Kierkegaard falando sobre Sócrates, mas é Marx falando sobre Hegel. O que não deve nos estranhar, já que Marx partilha a compreensão de sua época segundo a qual: "a ontologia de Hegel desconhecia relações diretas à existência e à observação reais" ${ }^{28}$.

Antes de discutirmos a saída fornecida por Marx a uma síntese não pensada mais como Aufhebung, notemos como este esquema é incrivelmente próximo do que podemos encontrar em Adorno. Lembremos, dentre tantos exemplos possíveis, do que está em jogo na enunciação de um dos conceitos centrais da dialética negativa, a saber, a noção de "lógica da desintegração" (Logik des Zerfall). Adorno quer lembrar como na dialética não se trata, inicialmente, de integrar processos no interior de determinações representacionais do conceito e de sua força de rememoração, mas de desintegrar este impulso inicial de unificação, lembrando que: "aquilo que poderia ser diverso, ainda não começou". Daí a necessidade de afirmar:

O movimento da dialética não tende para a identidade na diferença de cada objeto em relação a seu conceito; ela antes coloca o idêntico sob suspeita. Sua lógica é uma lógica da desintegração: da desintegração da figura construída e objetivada dos conceitos que o sujeito cognoscente possui imediatamente diante de $\mathrm{si}^{29}$.

Ou seja, a dialética não cria uma identidade através da integração da negatividade de cada objeto ao seu conceito, como vimos Marx denunciar Hegel e, por exemplo, seu Estado que desrealiza a família, mas conservando-a como momento parcial. A dialética desintegra a objetividade inicial dos conceitos. Pois a negatividade dos objetos não são apenas integradas ao conceito. Elas, na verdade, empurram os conceitos para além de si mesmos, para um ponto de transformação de sua força normativa inicial. Esta desintegração é a forma adorniana de recusar a figura da síntese dialética como Aufhebung, com seu jogo de negação e conservação.

Notemos ainda a dupla via de uma mesma crítica. Enquanto Marx afirmava que, ao integrar através do conceito, Hegel desrealizava relações concretas, conservando o que deveria ser não apenas superado, mas anulado a fim de que uma outra configuração da existência emerja, Adorno afirma que tal integração elimina o potencial de transformação próprio à atualização de experiências em latência esquecidas no passado,

\footnotetext{
${ }^{28}$ LÖWITH, Karl. De Hegel a Nietzsche, Paris: Gallimard, p. 152.

${ }^{29}$ ADORNO, Dialética negativa. p. 127/ ND, p. 148.
} 
experiências que poderiam fazer uma nova existência emergir. Daí porque ele afirma, em um tom radicalmente próximo do jovem Marx falando da ideia como uma força de abstração:

Na medida em que, a cada novo nível dialético, Hegel se esquece, contra a intelecção intermitente de sua própria lógica, do direito próprio ao que é anterior, ele prepara o molde daquilo que ele acusa como negação abstrata: positividade abstrata, isto é, ratificada a partir do arbítrio subjetivo ${ }^{30}$.

Notemos o que diz Adorno: a consciência hegeliana é uma força de paralisia porque, ela esquece daquilo que não se constituiu no passado como experiência totalmente determinada e conceitualmente organizada. Por isto, ela prepara o molde de um passado como positividade abstrata. Pois o que teria direito próprio no nível precedente, segundo Adorno, é aquilo que não se realizou nem no passado nem no presente, é aquilo mutilado pelos processos de racionalização social. Este retorno ao que ficou no nível precedente é a maneira adorniana de apontar para a força disruptiva do que permaneceu não integrado pelo progresso e pelo desenvolvimento, isto em um esquema de pensamento baseado na insistência freudiana de recuperação do que não se integra em uma maturação pensada a partir do desenvolvimento teleológico.

Esta ampliação das estratégias da crítica feita por Adorno tem sua razão histórica. Vimos como Marx critica a dialética hegeliana por ter em vista um horizonte histórico marcado pelo caráter retardatário da realidade alemã e seu sistema de "compensações simbólicas" através do recurso às dinâmicas de superação produzidas pela Ideia. Já Adorno, nos anos 50 e 60 do século XX (momento em que ele se volta de forma mais sistemática para a reconstrução da dialética), não está exatamente diante de um horizonte histórico de descompasso entre avanço da Ideia e atraso da efetividade. Mais correto seria dizer que ele se confronta com um momento histórico de aparente fortalecimento da capacidade de organização sistêmica do capitalismo e de seu horizonte normativo através dos desdobramentos do "capitalismo de estado" ${ }^{31}$. Uma organização que se expressa não apenas em um sistema até então inédito de gestão de crises e de previsão de demandas através de instâncias nãoprivadas de regulação, sistema que leva Adorno a afirmar que nossa

\footnotetext{
${ }^{30}$ Idem, p. 138/ ND, p. 162.

${ }^{31}$ Ver o influente POLLOCK, Friedrich. "State capitalism: its possibilities and limitations"; IN: ARATO, Andrew e GEBHARDT, Eike. The essential Frankfurt School reader, Nova York: Continuum, 1983, pp. 71-93. Nele, encontramos a tese da passagem inexorável de um "capitalismo privado" para um capitalismo de alta regulação estatal, seja ele totalitário ou democrático. Capitalismo no qual as decisões econômicas estariam submetidas à orientação política das deliberações de gestão. Pollock chega a falar em uma substituição de problemas econômicos por problemas administrativos, criando um horizonte "racional" de gestão.
} 
época conheceria uma predominância da força sistêmica das relações de produção sobre o caráter disruptivo das forças produtivas ${ }^{32}$. Adorno insistirá também em um processo convergente de gestão social no qual os campos da cultura e da economia, assim como dinâmicas sociais de trabalho, desejo e linguagem, obedecem a um profundo processo de integração.

Este horizonte aparece a Adorno como um horizonte de máxima integração que se traduz em um princípio social de paralisia e conservação ainda mais problemático do que aquele apontado por Marx, já que a integração entre força reguladora do Estado e mercado permitiria a limitação dos processos de pauperização e precarização que poderiam ser o fundamento de um sofrimento social capaz de levar a ações de ruptura. Mas esta pretensa limitação dos processos de espoliação econômica (afinal, é sempre bom lembrar, Adorno não viu a ascensão neoliberal dos anos setenta, seu horizonte é o da ascensão do Estado providência) seria pago pelo aprofundamento das dinâmicas de alienação social através da industrialização do campo da cultura e a consequente estereotipia das relações intersubjetivas e das relações a si. O que explica a insistência em compreender a irredutibilidade da alienação mesmo em situações nas quais a espoliação teria pretensamente sido controlada.

$E$ É neste horizonte histórico que se inscreve a crítica à dialética hegeliana, assim como a tentativa de transformar a dialética em uma lógica da desintegração, retirando do primeiro estágio da cena discussões sobre modalidades de realização de uma totalidade verdadeira, de um Estado justo e de reconciliação. Retirar tais discussões do primeiro estágio da cena é a forma adorniana de afirmar que os modelos contemporâneos de gestão social impedem a enunciação filosófica de conceitos nos quais a crítica outrora depositou sua força afirmativa. Mas a aposta no nãorealizado, no "direito do que era anterior" é a forma adorniana de insistir que a gestão social não é total, que o caráter disruptivo dos antagonismos e da contradição ainda continua em operação. A dialética continua revolucionária se deslocar seu sistema de posições e pressuposições, retraindo a enunciação de certos horizontes de reconciliações e operando mais claramente como dialética negativa.

Neste sentido, se configurações importantes da estratégia adorniana eram resultantes da tomada de posição a respeito de uma situação histórica fundada no advento do Estado providência, há de se notar que o colapso atual desta situação e a consolidação de uma alternativa neoliberal recoloca a crítica diante de uma sociedade com baixa capacidade de integração e alto potencial de antagonismo. Desta forma, a crítica pode insistir novamente em dinâmicas necessárias de

\footnotetext{
${ }^{32}$ Ver, principalmente, ADORNO, Theodor. "Spätkapitalismus oder Industriegessellschaft?", In: Soziologische Schriften I, Frankfurt: Suhrkamp, 1972.
} 
emergência de sujeitos políticos, em uma certa recuperação de modelos presentes em Marx. Voltaremos a este ponto no final deste artigo.

\section{Mimesis como síntese e apropriação sem possessão}

Por enquanto, tentemos entender melhor a solução proposta por Marx à síntese dialética, pois isto nos permitirá compreender de forma mais precisa as estratégias adornianas. Marx está atento ao fato da Aufhebung hegeliana, com sua conciliação entre sujeito e objeto, exigir a emergência de um outro sujeito como narrador do movimento do conceito e de reconstrução das imagens de mundo. É esta emergência que lhe interessa com seu potencial de reconciliação, mesmo que as figuras determinadas por Hegel lhe apareçam como criticáveis. Ou seja, do movimento da Aufhebung com suas superações de contradições, Marx conserva a temática da emergência de novos sujeitos, o que será um tópico fundamental para sua teoria da revolução ${ }^{33}$.

Neste sentido, lembremos como há ao menos duas transformações na estrutura do sujeito descritas por Hegel. A primeira refere-se à passagem da consciência à consciência-de-si, enquanto a segunda referese à passagem da consciência-de-si ao Espírito. A duas saídas, e suas formas pressupostas de síntese, serão criticadas por Marx.

Sabemos como, em Hegel, consciência-de-si é um conceito relacional e, por isto, difere do conceito simples de consciência. Ele descreve modos de implicação entre sujeito e objeto e modos de relação entre sujeitos. Marx admite a natureza relacional do conceito de consciência-de-si, mas insiste que ela representa apenas um modelo abstrato de implicação. Neste sentido, lembremos que uma das razões pelas quais Marx abandona o modelo de síntese como rememoração da consciência-de-si é a insistência em uma outra forma de síntese que deve ser compreendida como o que poderíamos chamar de "implicação multilateral através da sensibilidade", modelo tão presente nas discussões a respeito da relação de "metabolismo" entre humano e natureza. Ou seja, há uma síntese entre sujeito e objeto que passa pela sensibilidade e que só pode ser transformada pela sensibilidade, transformada pela indução material que opera no nível da sensibilidade.

Neste sentido, há de se falar em indução material da sensibilidade porque tudo se passa como se apenas a modificação de configurações

\footnotetext{
${ }^{33} \mathrm{O}$ que aparece, por exemplo, no Lukács de História e consciência de classe através da temática da emergência histórica do proletariado como "sujeito-objeto idêntico", como vemos em afirmações como: "Apenas quando a consciência do proletariado é capaz de indicar o caminho para o qual concorre objetivamente a dialética do desenvolvimento, sem no entanto poder cumpri-lo em virtude da sua própria dinâmica, é que a consciência do proletariado despertará para a consciência do próprio processo; somente então o proletariado surgirá como sujeito-objeto idêntico da história, e a sua práxis se tornará uma transformação da realidade" (LUKÁCS, György. História e consciência de classe, São Paulo: Martins Fontes, 2003, p. 391).
} 
materiais (intensidades, ritmos, funcionalidades) pudesse, de fato, modificar os modos de determinação da experiência e permitir a efetiva emergência de novos sujeitos. No entanto, não é a redescrição conceitual ou categorial que mudará tais configurações, mas apenas a remodelagem das próprias condições materiais nas quais a experiência sensível está inserida e se repete. Marx compartilha com Feuerbach a tentativa de recuperar a centralidade da sensibilidade, "situar de novo a receptividade sensível no início da filosofia" ${ }^{4}$, mesmo que ele lembre, contra Feuerbach, que a sensibilidade e suas formas são resultantes da sedimentação de experiências sócio-históricas que desconhece invariantes. Mas tal dimensão, e este é a ponto central, não pode ser modificadas apenas apelando à reflexão e à historicização. Ela exige uma modificação propriamente material $^{35}$.

$\mathrm{Na}$ verdade, isto é consequência da compreensão de materialismo significar também: reconhecer que a própria sensibilidade, em seus regimes de relação e afecção, produz formas de pensamento ${ }^{36}$. Ela não é apenas recepção de uma matéria inerte que receberia forma através da espontaneidade do entendimento e da sua submissão a uma compreensão autárquica dos estágios do conhecimento. Daí porque uma mudança na estrutura da sensibilidade é revolução na relação à natureza, ao mundo dos homens e à si mesmo. O que nos leva a afirmar que a transformação

\footnotetext{
${ }^{34}$ MARCUSE, Herbert. Materialismo histórico e existência, São Paulo: Tempo Brasileiro, 1968, p. 122
}

${ }^{35}$ A este respeito, lembremos como Backhaus (BACKHAUS, Hans-Georg. Dialektik der Wertform: Untersuchungen zur marxschen Ökonomiekritik, Berlin: Verlag, 2011) insiste com propriedade que a dialética da forma-valor, no Marx de $O$ Capital, exige uma modificação sensível dos objetos que entram em relação no interior de uma equação de valor. Dizer, por exemplo, que 20 quilos de arroz valem um livro implica que a primeira mercadoria se transforma em algo materialmente diferente do que era. Ela encarna outro objeto, que aparece como a expressão imediata do valor. No interior da relação entre coisas, ela perde sua corporeidade e assume um corpo outro. Tal mutação implica a naturalização sensível de uma abstração, ou melhor, a naturalização de um movimento de mutação e incorporação contínua. Tal intercambialidade absoluta, e este é o ponto que gostaria de insistir, modifica a estrutura sensível do mundo, abrindo o espaço a uma experiência da autonomia absoluta do valor. Sua modificação, no entanto, exige uma ação no nível da sensibilidade e das estruturas de reprodução material.

${ }^{36}$ Lembremos como este é um tópico fundamental para o desenvolvimento do conceito de "abstração real", tão importante para Adorno. Há de se levar a sério afirmações de SohnRetel como: "A abstração da ação de troca é o efeito direto de uma causalidade por manipulação e não se apresenta imediatamente de forma nenhuma no conceito" (SOHN-RETHEL, Alfred. Trabalho manual espiritual: para a epistemologia da história ocidental, In: http://ideiaeideologia.com/wp-content/uploads/2012/10/sohn-retheltrabalho-manual-e-espiritual.pdf. Deriva-se daí que a abstração produzida pela formamercadoria se impõe através da modificação qualitativa da experiência sensível, e não através da reflexividade do conceito. 
social deverá ser vista também como uma "revolução total de todo seu modo de sensação" 37 .

Como sabemos, a importância de Schiller para o jovem Marx é evidente. Da mesma forma, é a partir deste ponto, desta proximidade ao jovem Marx, e não devido a alguma forma de escapismo aristocrático ou de lógica compensatória aos bloqueios da transformação social, que devemos compreender a importância dada a Adorno à práxis estética como antecâmara para a emancipação efetiva. No que devemos meditar a importância de afirmações como:

Se a sociedade sem classes promete o fim da arte, devido à superação da tensão entre o real e o possível, ela também promete o começo da arte, do desprovido de uso (Unnütze), cuja visão (Anschauung) tende à reconciliação com a natureza, porque deixou de estar a serviço do uso para os exploradores ${ }^{38}$.

A sociedade sem classes abole a funcionalização das coisas pelo uso, abrindo as coisas à realização de uma latência do real que permite uma experiência estética que é emancipação em relação aos mecanismos disciplinares da dominação, que é implicação multilateral através da sensibilidade. Mais do que qualquer outro, este ponto expõe a filiação marxista de Adorno, assim como explica a insistência de Marx em discutir a alienação da consciência através das condições inerentes ao trabalho social. Mais do que qualquer outro, este ponto define a distância entre Hegel e Marx. Por isto, a discussão marxista sobre a alienação no trabalho não deve ser compreendida apenas a partir da tópica da crítica da espoliação do objeto trabalhado e do tempo de trabalho. $\mathrm{Na}$ verdade, ela deve ser compreendida principalmente a partir de uma crítica geral ao próprio trabalho enquanto modo de apropriação do objeto e de organização da sensibilidade ${ }^{39}$. Pois o trabalho capitalista é forma disciplinar que determina modos de experiência do tempo, do espaço, das intensidades e da atenção a partir de exigências de autovalorização do valor com seus protocolos de abstração real. Exigências estas que se autonomizam em relação aos sujeitos, criando um princípio de troca capaz de reconfigurar os modos gerais de determinação social no interior do capitalismo, além de se impor como forma autônoma de valor até mesmo em relação à noção primeira de valor como expressão de quantum de trabalho (em si, já uma abstração) ${ }^{40}$.

${ }^{37}$ SCHILLER, Friedrich. A educação estética do homem, São Paulo: Iluminuras, 2011, p. 129 [tradução modificada]. A respeito das relações entre Schiller e o jovem Marx, ver FAUSTO, Ruy. Marx: lógica e política III, São Paulo: Editora 34, 2010

${ }^{38}$ ADORNO, Theodor. Soziologische Schriften I, op. cit., p. 396

${ }^{39}$ Sobre este ponto, ver, principalmente POSTONE, Moshe. Tempo, trabalho e dominação social, São Paulo: Boitempo, 2014

${ }^{40}$ Neste sentido, vale a consideração de Helmut Reichelt: "a crítica marxiana da economia política não consiste em uma nova versão da assim chamada teoria do valor do trabalho 
Lembremos ainda que o trabalho é modo de relação aos objetos baseado em uma forma específica de determinação, a saber, a forma da propriedade. Daí porque não é correto dizer que a síntese em Marx será marcada pela emergência de uma nova figura da consciência que trabalha. Ela será emergência de um sujeito cuja atividade não pode mais ser pensada a partir das figuras do trabalho, atividade que produz sínteses que não podem mais ser compreendidas a partir do paradigma do trabalho, de seus modos de relação e de sua produção do valor. Ou seja, e para Marx esta consequência é fundamental, a síntese dialética exige a derrocada das relações materiais que sustentam a sociedade do trabalho. O que talvez nos explique porque, já em O Capital, Marx deverá insistir em vincular a dialética a uma teoria da revolução:

Em sua configuração racional, a dialética constitui um escândalo, um horror para a burguesia e seus porta-vozes doutrinários, uma vez que, o entendimento positivo do existente/permanente (Bestehenden), inclui, ao mesmo tempo, o entendimento de sua negação, de sua necessária passagem (Untergangs). Além disso, apreende toda forma desenvolvida no fluxo do movimento, portanto, incluindo o seu lado transitório; porque não se deixa intimidar por nada e é, por essência, crítica e revolucionária ${ }^{41}$.

Lembremos, no entanto, um ponto nem sempre explicitado: este entendimento da negação necessária do existente, este modo de apreender a forma no fluxo do movimento é, em Marx, inseparável da compreensão dinâmica de uma experiência de implicação sensível que a sociedade do trabalho procura eliminar e impedir. Por isto, a dialética, ao compreender formas desenvolvidas em movimento de autonegação, só pode se realizar como crítica do trabalho. A fim de melhor compreender a natureza desta experiência, voltemos a uma temática fundamental já presente desde o jovem Marx:

A superação [Aufhebung] positiva da propriedade, a apropriação sensível da essência e da vida humanas, do ser humano objetivo, da obra humana para e pelo homem, não pode ser apreendida apenas no sentido do gozo [Genusses] imediato, unilateral, não somente no sentido da posse, no sentido do ter. O homem se apropria da sua essência multilateral [allseitiges] de uma forma multilateral, portanto como um homem total. Cada uma de suas relações humanas com o

(isso também) mas - é isso que diferencia a crítica marxiana de todo teoria econômica - é o desenvolvimento teórico dessa distorção e autonomização reais. O conceito de crítica nesse sentido é idêntico ao conceito de exposição como desenvolvimento genético gradativo dessa autonomização, a partir de um 'princípio real'; Adorno o chama de princípio de troca" (REICHELT. Sobre a estrutura lógica do conceito de Capital em Karl Marx, Campinas: Edunicamp, p. 14).

${ }^{41}$ MARX, Karl. Das Kapital - Erster Band, Berlin: Karl Dietz Verlag, 2015, p. 28. 
mundo, ver, ouvir, cheirar, degustar, sentir, pensar, intuir, perceber, querer, ser ativo, amar, enfim todos os órgãos da sua individualidade, assim como os órgãos que são imediatamente em sua forma como órgãos comunitários, são no seu comportamento objetivo ou no seu comportamento para com o objeto a apropriação do mesmo, a apropriação da realidade humana; seu comportamento para com o objeto é o acionamento/a ativação [Bethätigung] da realidade humana (por isso ela é precisamente tão múltipla quanto múltiplos são as determinações essenciais e atividades humanas), eficiência humana e sofrimento [Leiden] humano, pois o sofrimento, humanamente apreendido, é um gozo de si [Selbstgenuss] do ser humano ${ }^{42}$.

Há vários tópicos fundamentais aqui que estarão presentes para além dos limites do jovem Marx. Notemos inicialmente como esta apropriação não é submissão do objeto à unilateralidade da função, da utilidade e, principalmente, da posse. Por isto, entre sujeito e objeto não pode passar uma relação de propriedade (no duplo sentido da palavra). Tudo se passa como se Marx falasse de uma peculiar "apropriação [Aneignung] sem possessão [Besitzen]", uma apropriação que é forma de síntese entre sujeito e objeto sem ser subsunção do objeto ao sujeito.

Se nos perguntarmos porque, afinal, esta apropriação sem possessão não pode ser pensada sob a forma do trabalho, deveremos lembrar que o trabalho é, inicialmente, uma forma de possessão, uma forma de transferência da forma humana às coisas, transferência da identidade do sujeito à matéria do objeto. Já em Locke encontramos essa assunção canônica da relação entre trabalho e identidade através da possessão do objeto trabalhado. Tenho direito aos objetos nos quais trabalho, eles são minhas propriedades porque dou a eles a forma da minha própria exteriorização. Eu os subsumo através do trabalho ${ }^{43}$.

No entanto, Marx está a falar de relações com objetos que sinto, que vejo, que percebo, que amo sem possui-los, sem submetê-los à condição de minha propriedade, sem submete-los à condição de expressões de minhas predicações. Mas é exatamente por sermos afetados por objetos que não se submetem à condição daquilo que tenho, pela percepção ser abertura a objetos que (sem temer pecar por anacronismo) não me são completamente idênticos, que esta afeção sensível pelo que nunca possuirei pode ser uma ativação da realidade

\footnotetext{
${ }^{42}$ MARX, Karl. Ökonomisch-philosophische Manuskripte, op. cit., p. 120.

43 "Ainda que a Terra e todas criaturas inferiores sejam comuns a todos os homens, cada homem tem a propriedade de sua própria pessoa. Disto, ninguém tem direito a não ser ele mesmo. O trabalho (Labour) do seu corpo e a obra (Work) de suas mãos são propriamente ele. Tudo o que ele remove para fora do que o estado de natureza providenciou e foi nele deixado, ele misturou com seu trabalho, adicionando algo que é propriamente seu, fazendo isto então sua propriedade". (LOCKE, John. Two treatises of government, Cambridge University Press, 1988, p. 288).
} 
humana ${ }^{44}$. Esta síntese que opera no nível da sensibilidade é uma relação entre não-idênticos que transforma mutuamente cada um dos termos em relação.

É deste horizonte de reflexão a respeito de induções materiais da sensibilidade e de formas de apropriação sem possessão que modificam as determinações essenciais da relação entre humanidade e natureza que Adorno parte e é ele que, de certa forma, sustenta sua relação tensa e problemática a Hegel. As discussões de Adorno a respeito do uso da mimesis como modo de mediação e síntese serão, em larga medida, incompreensíveis se não retornarmos ao horizonte de problemas estabelecido pelo jovem Marx.

Esta aproximação serve, entre outras coisas, para nos lembrar como os conceitos adornianos tem um potencial político crítico na medida em que apontam para a superação de uma sociedade do trabalho. Adorno insiste que o diagnóstico marxista da alienação como sofrimento social resultante da constituição das nossas sociedades como sociedades do trabalho, sociedades no interior da qual toda atividade é orientada para a valorização do valor, continua absolutamente válido. $\mathrm{Na}$ verdade, este processo foi aprofundado através da generalização do consumo ao consumo de valores de troca (daí o uso generalizado da temática do fetichismo para o campo da produção cultural). Neste sentido, a mimesis, com sua apropriação sem possessão, com sua assimilação sem identidade, não pode sobreviver no interior de uma sociedade do trabalho (o que explica porque ela sobrevive em sociedades pré-capitalistas ${ }^{45}$ ), sociedades no interior da qual as relações estão submetidas à abstração geral da identidade. Ou antes, ela só pode sobreviver como atividade de combate que procura abrir espaço a outras modalidades de práxis social, assim como indica condições para a emergência de sujeitos com força de transformação em um horizonte no qual "a identidade é a forma originária

\footnotetext{
${ }^{44}$ Este é um eixo importante da leitura adorniana de Marx, o que explica afirmações como: "Em suas parcas exposições sobre a constituição de uma sociedade livre, o Marx maduro alterou sua relação com a divisão do trabalho, com o fundamento da reificação. Ele distingue estado de liberdade e imediatez primitiva. No momento da planificação, do qual ele esperava uma produção voltada para os viventes em vez de para o lucro, e, em certo sentido, esperava também a restituição da imediatez, conserva-se o coisalmente estranho" (ADORNO, Theodor. Dialética negativa, p. 164/ ND, p. 193). Este é um ponto fundamental que explica a surpreendente afirmação adorniana de que centralizar toda a crítica social em torno da crítica da reificação seria um erro, seria só uma maneira de tornar a teoria crítica aceitável de maneira idealista para a consciência dominante. Pois a crítica da reificação pressupõe a figura da consciência em suas formas de apropriação. Não se sai do fetichismo da mercadoria para se entrar no fetichismo da consciência e continuar o dogma metafísica da distinção entre pessoas e coisas. Mais importante seria lembrar que "não se pode excluir da dialética do estabelecido aquilo que a consciência experimenta como estranho", experiência do que exige uma crítica das próprias figuras da consciência e de suas representações.

${ }^{45}$ Cf. ADORNO e HORKHEIMER. Dialética do esclarecimento, Rio de Janeiro: Jorge Zahar, 1994, principalmente os primeiros capítulos.
} 
da ideologia". Uma modalidade de práxis na qual o sujeito, compreendendo que porta em si algo da opacidade dos objeto, age não mais como uma consciência autônoma, mas como quem deve se confrontar com a heteronomia do que se coloca como inconsciente. Daí porque:

A construção do sujeito-objeto possui uma duplicidade insondável. Ela não se contenta em falsificar ideologicamente o objeto e em transformálo no ato livre do sujeito absoluto, mas também reconhece no sujeito o objetivo apresentando-se e que limita anti-ideologicamente o sujeito ${ }^{46}$.

Retirar a reflexão sobre a relação sujeito-objeto do horizonte, como se estivéssemos diante de meras dicotomias anacrônicas do idealismo, é para Adorno um equívoco maior. Pois a relação sujeito-objeto expressa também como o sujeito se confronta com algo que o restringe, algo que limita sua tendência à projeção. Por isto, mesmo se: "o antagonismo que a filosofia reveste com as palavras 'sujeito' e 'objeto' não pode ser interpretada como um estado de coisas originário" ${ }^{47}$, há de se lembrar que tal antagonismo não pode ser eliminado "apenas por meio do espírito".

É neste contexto que podemos entender melhor como o uso adorniano do conceito de mimesis nos leva ao reconhecimento de uma dimensão fundamentalmente somática dos modos de relação. $O$ que é mimeticamente relacionado é sensivelmente implicado, e não apenas conceitualmente organizado. Pois a insistência na mimesis é forma de definir um regime sensível de afinidade e de implicação. Daí a importância de afirmar: "enquanto momento não puramente cognitivo do conhecimento, o momento somático é irredutível" 48 .

Apelar a irredutibilidade do momento somático não é, no entanto, fazer alguma forma de profissão de fé irracionalista. O materialismo adorniano é perspectiva que reconhece que nenhuma atividade é sem substrato e que tal substrato, descrito como momento somático, tem um movimento de implicação e transformação que lhe é próprio. Gostaria de defender este momento somático é o que, à sua maneira, Marx mobiliza contra o conceito hegeliano de consciência-de-si e suas formas de síntese.

\section{Breve tratado de história natural}

Neste sentido, tal ativação da realidade humana produzido por outra forma de síntese entre sujeito e objeto não pode ser simplesmente compreendido como desvelamento de que o objeto nada mais é do que produção humana e social. Pois não estamos a falar apenas do modelo de

\footnotetext{
${ }^{46}$ ADORNO, T. Dialética negativa, p. 290/ ND, p. 343

${ }^{47}$ Idem, p. 166

${ }^{48}$ Idem, p. 166.
} 
uma realidade humana, anteriormente reificada, que se reencontra nos objetos que ela mesma produziu. Não estamos apenas diante de uma versão da temática pascaliana da segunda natureza. Estamos também a falar de uma realidade humana que se transforma ao reconhecer os objetos que lhe afetam. Pois a apropriação da natureza histórico-social do objeto não poderia, no final das contas, ser apenas uma peculiar e contraditória, apenas em aparência, figura materialista da subsunção idealista do objeto pelo sujeito, o que nos levaria mais uma vez a formas astutas de psicologismo subjetivista. Ela precisa ser abertura à capacidade do mundo afetar a percepção e modificá-la. Para tanto, faz-se necessário uma capacidade de indução material da sensibilidade.

Marx descreve uma dinâmica reflexiva simétrica ao afirmar, por exemplo: "Só posso relacionar-me praticamente à coisa, se a coisa se relaciona humanamente ao ser humano" 49. Mas perderemos completamente o horizonte do pensamento de Marx se não compreendermos como proposições desta natureza pressupõe $a$ modificação qualitativa da noção de "humano". A coisa se relaciona humanamente ao ser humano não apenas porque ela se desvelou como consciência, não apenas porque ela não era mais do que consciência reificada que velava o sentido especificamente humano de sua existência humanamente produzida. Um mundo desta natureza só poderia ser um mundo de fetichismo generalizado.

$\mathrm{Na}$ verdade, a coisa pode se relacionar humanamente ao ser humano porque estamos a assistir uma mutação do significado do termo "humano", no qual ele perde seu caráter excludente (humano como o que se diferencia do animal, como o que se diferencia do natural, da coisa, entre outros) e descreve um campo de mútua implicação, de contínuo metabolismo entre o humano e o que, até então, estava aquém do humano. Não só a natureza se humaniza, mas o humano, de certa forma, "deshumaniza-se", pois se alarga e incorpora o que, até então, não cairia sob a definição de "humano". Esta seria a única resposta adequada ao problema do fetichismo.

Este ponto é fundamental se não quisermos retornar a uma noção de subjetividade constituinte, simplesmente agora acrescida de sua dimensão social e de uma profundidade histórica. A este respeito, é fato que Marx critica todo empirismo que procure desconhecer a natureza histórico-social de nossos sentidos: "a formação dos cinco sentidos é um trabalho de toda a história do mundo até aqui" ${ }^{50}$. Este é mesmo um dos

\footnotetext{
${ }^{49}$ MARX, Karl. Ökonomische-philosophische Manuskript, op. cit., p. 121.

${ }^{50}$ Idem, p. 103. Lembremos, neste sentido, da importante colocação de Ruy Fausto: "Se a história na Ideologia alemã é história da liberdade (história da constituição da liberdade, embora o texto não a apresente assim), se nos Grundrisse ela é história da constituição da riqueza, apresentação da riqueza, a história nos Manuscritos é história da constituição da satisfação e do gozo, a apresentação deles. E se na Ideologia alemã tem-se a educação do homem para a liberdade (isto ocorre com a revolução e através dela), se nos Grundrisse
} 
eixos de sua distância em relação a Feuerbach. Mas esta história do mundo não pode ser apreendida sem que ela tenha um momento de "história natural", de história cristalizada na exterioridade das formas naturais: "a história mesma é uma parte efetiva da história natural, do devir da natureza até o homem" ${ }^{51}$, isto a ponto do jovem Marx insistir na necessidade de unificação entre ciências naturais e ciência dos homens. A formação dos cinco sentidos é resultado histórico do desenvolvimento humano em seu contato com o mundo, da transformação da sensibilidade a partir do contato, historicamente distendido, com o mundo. De outra forma, seria difícil distinguir as formas atuais da percepção de um simples delírio socialmente partilhado. De certa forma, é isto que leva Adorno, confrontando-se com o conceito de história natural, a afirmar:

A antítese tradicional entre natureza e história é verdadeira e falsa; verdadeira na medida em que enuncia o que acontece com o momento

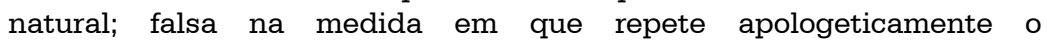
encobrimento da naturalidade da história por meio dessa história mesma graças à sua construção conceitual a posteriori ${ }^{52}$.

Ou seja, a dicotomia entre natureza e história é verdadeira enquanto expressa o destino histórico da natureza, a saber, ser reduzida a espaço de experiências apartado da afirmação do humano e que, por isto, pode se submeter à distinção ontológica entre coisas e pessoas. Ela é falsa, no entanto, por impedir o desvelamento da história no seio da natureza, assim como da natureza enquanto eixo e motor da história. Ou seja, por ontologizar uma situação resultante de configuração histórica específica ${ }^{53}$. Isto leva Adorno a afirmar:

Cabe ao pensamento ver toda natureza e tudo aquilo que viesse a se instalar como tal enquanto história e toda história enquanto natureza: seria preciso compreender o próprio ser histórico em sua determinidade histórica extrema, no âmbito em que ele é o mais histórico possível, como um ser natural, ou compreender a natureza, no âmbito em que ela

tem-se a "educação", a formação da riqueza, que, se transfigurando em logos, cria a verdadeira riqueza, o tempo livre, nos Manuscritos tem-se a educação dos sentidos" (FAUSTO, Ruy. Marx: lógica e política - volume III, op. cit., p. 157).

${ }^{51}$ MARX. Idem, p. 110.

${ }^{52}$ ADORNO, Theodor. Dialética negativa, p. 297.

${ }^{53}$ Neste sentido, há de se lembrar como: "a natureza orgânica e a inorgânica são negadas sob o capitalismo. A natureza foi negada precisamente porque a sociedade assume agora a forma mistificada de algo natural, enquanto o mundo natural é idealisticamente concebido como uma mera prefiguração das relações, instituições e práticas sociais. Devido a nossas ideias distorcidas sobre a natureza interna e externa, nossa experiência da natureza foi empobrecida, diminuída" (COOK, Deborah. Adorno on nature, Duhram: Acumen, 2011, p. 16). 
persiste em si aparentemente de maneira mais profunda, como um ser histórico ${ }^{54}$.

A essência de um pensamento realmente materialista estará em operar neste ponto de interpenetração entre natureza e história. Ponto no qual a história se intervém em natureza e a natureza se intervém em história pois as duas perderam sua aparência de compulsão podendo aparecer como a celebração conjunta da liberdade.

Por outro lado, podemos entender agora porque a dialética negativa é, necessariamente uma versão de dialética materialista. Uma materialismo não dialético iria se contentar com a descrição dos processos materiais de constituição de sistemas de ideias, seja esta descrição feita em chave empirista, seja feita em chave historicista. Em nenhum destes dois casos, temos dialética. A descrição da gênese material de sistemas de ideias não basta para termos uma perspectiva propriamente dialética. Ela basta para termos uma perspectiva materialista, e ponto. Para termos dialética, os processos materiais devem, ao mesmo tempo, negar e realizar o que apareceu inicialmente como ideia.

Por exemplo, os processos materiais negam a naturalização da história, mas eles ao mesmo tempo realizam a naturalização da história, agora em outro nível. Não porque dinâmicas históricas foram naturalizadas, mas porque a natureza deixou de ser compreendida como mero mecanicismo, como mera coisa pronta para ser funcionalizada e submetida à posse. Ela aparece agora como a homologia de uma dinâmica de liberdade, o que não deveria ser estranho para alguém como Marx, cujo materialismo nasce de uma reflexão sobre o lugar do acaso e da indeterminação no atomismo de Epicuro, ou para alguém como Adorno, cuja noção de natureza é próxima da teoria freudiana das pulsões. Desta forma, a natureza aparece como a realização de uma ideia que inicialmente apareceu exatamente como contraponto à natureza.

Da mesma forma, poderíamos dizer que o objeto nega e realiza o sujeito. Ele nega o sujeito ao resistir à subsunção idealista, resistir a ser a mera projeção de uma subjetividade constituinte. Mas, no mesmo movimento, ele o realiza por ser um momento da posição do próprio sujeito, que compreende agora como é habitado por "um núcleo do objeto", por algo que não é completamente consciência. Neste sentido, o sujeito é conservado, mas seu sentido passou no oposto e modificou sua configuração.

\section{O problema do proletariado}

Terminemos lembrando que tais questões poderiam requalificar melhor o problema que aparece como um dos eixos maiores de distinção entre a

\footnotetext{
${ }^{54}$ ADORNO, T. Dialética negativa, p. 298.
} 
dialética marxista e a dialética negativa e que evitei abordar durante todo este artigo. Mais do que uma saída que parece dar à contradição e à sua figura contemporânea (a não-identidade) uma dimensão ontológica, Marx insistiria em criticar a Aufhebung hegeliana a fim de permitir a emergência de uma negação absoluta de ordem tal que abrisse o espaço ao advento de um novo sujeito, no caso, o proletariado. De certa forma, é só com este novo sujeito e sua força de abolição do trabalho que a transformação da sensibilidade poderia ocorrer.

Ora, aprendemos todos como o horizonte da experiência filosófica adorniana seria marcado pelo colapso de todo processo de emergência de sujeitos políticos com potencial de transformação revolucionária devido ao diagnóstico sociológico da integração do proletariado no interior das dinâmicas do estado de bem-estar social, ao menos a partir da ótica do desenvolvimento do capitalismo europeu dos anos 50 e 60. Mesmo conservando o conceito sociológico de classe, insistindo que experiências de opressão social ainda justificam seu uso, Adorno insiste que nossa época conheceria uma predominância da estrutura das relações capitalistas de produção sobre o caráter disruptivo do desenvolvimento das forças produtivas. Este é um dos pontos que lhe leva a avaliar a ausência de consciência de classe no que deveria aparecer como o proletariado atual. $\mathrm{O}$ dado sociológico fundamental é a impossibilidade dos submetidos a espoliação e alienação atualmente se constituírem, para si mesmos, enquanto classe devido a fatores como: o extremo desenvolvimento monopolista do capitalismo e a própria ausência uma dinâmica de classe na burguesia (já que a espoliação devido à concentração monopolista afeta setores da própria burguesia), além da natureza disciplinar e hierárquica da própria noção de classe ${ }^{55}$.

De certa forma, Adorno de fato acredita que a expectativa de transformação depositada na classe sociológica dos trabalhadores proletários não pode ser mais posta. Mas há de se lembrar que o conceito de proletariado tem, em Marx, uma realidade que não é apenas sociológica. Ele descreve também uma posição ontológica ligada à despossessão generalizada como condição para a ação efetiva, assim como ligada à expressão da negatividade e da irredutibilidade às predicações como posição fundamental do sujeito ${ }^{56}$. Através de uma situação na qual sujeitos aparecem como profundamente despossuídos, os vínculos às atuais formas de vida e à seus regimes disciplinares se fragilizam, permitindo a emergência de um novo sujeito.

Em dado momento, Adorno afirma: "a confrontação (Gegenüberstellung) entre burguês e proletário nega tanto o conceito burguês de homem assim como os conceitos da economia burguesa" ${ }^{57}$. Colocações desta natureza,

\footnotetext{
${ }^{55}$ Cf. ADORNO, Theodor. "Reflexion zur Klassentheorie", In: Soziologische Schriften I, op. cit.

${ }^{56}$ Tentei desenvolver este ponto no quarto capítulo de SAFATLE, Vladimir. O circuito dos afetos, Belo Horizonte: Autêntica, 2016.

${ }^{57}$ ADORNO, Theodor. Soziologische Schriften I, p. 389.
} 
que articulam claramente crítica da economia política e crítica da estrutura disciplinar de constituição de figuras da subjetividade, mereceriam ser melhor exploradas. Pois se nos perguntarmos sobre o que caracteriza tal antropologia do sujeito burguês veremos uma certa ligação à identidade, à relações por propriedade, à abstração, à funcionalidade. Tais características necessariamente são negadas com o advento do proletariado. Assim, a dicotomia entre burguês e proletário não é apenas resultado de um problema de distribuição e de espoliação econômica (que, é sempre bom lembrar, retorna de forma muito mais forte no interior do neoliberalismo). Ela é expressão de um antagonismo a respeito de formas do sujeito, ou seja, um antagonismo sobre figuras da subjetividade. Isto a ponto de Adorno afirmar que o desaparecimento da autonomia do mercado e da individualidade burguesa implica o desaparecimento do seu oposto, a saber, a desumanização daqueles rejeitados pela sociedade. Esta desumanização não aponta, no entanto, para a perda do que a individualidade burguesa entende por "humanidade". Ela aponta para a impossibilidade da emergência de uma "humanidade" que nos retiraria desta pré-história contínua travestida de história da ascensão e hegemonia da burguesia. Neste sentido, lembremos de afirmações de Marx e Engels como:

A relação comunitária em que entram os indivíduos de uma classe, relação condicionada por seus interesses comuns frente a um terceiro, era sempre uma comunidade a qual pertenciam esses indivíduos somente na condição de indivíduos médios, somente enquanto viviam dentro das condições de existência de sua classe, uma relação que não os unia como indivíduos, mas como membros de uma classe. $\mathrm{Na}$ comunidade dos proletários revolucionários, ao contrário, que tomam sob seu controle suas condições de existência e a de todos os membros da sociedade, ocorre justamente o oposto; tomam parte dela os indivíduos como indivíduos ${ }^{58}$.

Notem a distinção feita por Marx e Engels. Antes do advento do proletariado como classe revolucionária, os indivíduos só formavam classes enquanto resposta a uma luta comum contra um terceiro, contra outra classe. Ou seja, a classe aparece assim como uma associação condicionada pela existência de um terceiro excluído, dentro dos usos políticos da distinção amigo/inimigo. Mas por ser uma estrutura defensiva, ela necessariamente definirá os indivíduos a partir de um modo de pertencimento baseado na partilha geral de atributos diferenciais que constituem a classe como um conjunto. A classe funda assim uma identidade por partilha de atribuição e toda identidade desta natureza é sempre uma operação defensiva. Daí a ideia de que, no interior da classe, os indivíduos aparecem apenas como indivíduos médios, ou seja,

\footnotetext{
${ }^{58}$ MARX e ENGELS. Ideologia alemã, p. 102.
} 
indivíduos submetidos a um padrão, a uma mediana com a qual todos devem se conformar.

Já na associação de indivíduos livres produzida pelo proletariado os indivíduos podem aparecer como indivíduos não mais submetidos à uma definição de classe. Primeiro, eles não se submetem mais à divisão do trabalho, por isto sua atividade não é compreendida como trabalho. Como dirão Marx e Engels, o proletariado elimina o trabalho. Por outro lado, eles não se confrontam mais com um terceiro excluído, por isto sua ascensão é a dissolução de todas as classes, é o fim da compreensão da vida social como constituída por classes e a realização possível do da totalidade própria ao ser do gênero. Marx e Engels chegam a falar em: "apropriação de uma totalidade de forças produtivas e no consequente desenvolvimento de uma totalidade de capacidades" ${ }^{59}$. Esta apropriação da totalidade só é possível porque não há mais uma perspectiva de classe em operação. Neste momento, uma outra história começa: uma história do ser humano.

\section{Referências bibliográficas}

ADORNO, Theodor. Dialética negativa, Rio de Janeiro: Jorge Zahar, 2009.

ADORNO, Theodor. Negative Dialektik, Frankfurt: Suhrkamp, 1973.

ADORNO, Theodor; "Spätkapitalismus oder Industriegessellschaft?", In: Soziologische Schriften I, Frankfurt: Suhrkamp, 1972.

ADORNO e HORKHEIMER. Dialética do esclarecimento, Rio de Janeiro: Jorge Zahar, 1994.

ARATO, Andrew e GEBHARDT, Eike; The essential Frankfurt School reader, Nova York: Continuum, 1983.

ARANTES, Paulo; Ressentimento da dialética, São Paulo: Paz e Terra, 1996

BACKHAUS, Hans-Georg; Dialektik der Wertform: Untersuchungen zur marxschen Ökonomiekritik, Berlin: Ça ira Verlag, 2011.

BADIOU, Alain; " La dialectique negative d'Adorno "In : Cinq leçons sur le 'cas' Wagner, Paris : Nous, 2010.

COOK, Deborah. Adorno on nature, Duhram: Acumen, 2011.

DELEUZE, Gilles; Nietzsche et la philosophie, Paris: PUF, 1962.

FAUSTO, Ruy. Marx: lógica e política III, São Paulo: Editora 34, 2010.

${ }^{59}$ Idem, p. 95. 
V. P. Safatle - Materialismo e Dialéticas sem Aufhebung: Adorno, leitor de Marx; Marx, leitor de Hegel

HABERMAS. O discurso filosófico da modernidade, São Paulo: Martins Fontes, 2002.

HEGEL, G.W.F.; Phänomenologie des Geistes, Hamburgo: Feliz Meiner, 1988.

HEGEL, G.W.F.; Grundlinien der Philosophie des Rechts, Frankfurt: Suhrkamp,1986.

HIPPOLYTE, Jean; Gênese e estrutura da Fenomenologia do Espírito, São Paulo: Discurso Editorial, 2004.

HÖSLE, Vittorio; O sistema de Hegel: o diealismo da subjetividade e o problema da intersubjetividade, Belo Horizonte: Loyola, 2007.

LOCKE, John. Two treatises of government, Cambridge University Press, 1988.

LÖWITH, Karl; De Hegel à Nietzsche, Paris: Gallimard, 1969.

LUKACS, Gyorg; História e consciência de classe, São Paulo: Martins Fontes, 2003.

MARX, Karl; Crítica da filosofia do direito de Hegel, São Paulo: Boitempo, 2005.

MARX, Karl. Das Kapital - Erster Band, Berlin: Karl Dietz Verlag, 2015.

MARX, Karl; Ökonomisch-philosophische Manuskripte, Frankfurt: Suhrkamp, 2015.

MARX, Karl; Zur Kritik der Hegelschen Rechtphilosophie. Einleitung, In:

Gesammelte Werke, Colônia: Anaconda, 2016.

MARX, Karl e ENGELS, Friedrich; $A$ ideologia alemã, Rio de Janeiro: Civilização Brasileira, 2007.

MCDOWELL, John; Having the world in view: essays on Sellars, Kant and Hegel, Harvard University Press, 2009.

PIPPIN, Robert; "Negative ethics: Adorno on the falsehood of bourgeois life" In: The persistence of subjectivity: on the Kantian aftermath, Cambridge University Press, 2005.

POSTONE, Moshe. Tempo, trabalho e dominação social, São Paulo: Boitempo, 2014.

POLLOCK, Friedrich; "State capitalism: its possibilities and limitations"; IN:

MARCUSE, Herbert; Materialismo histórico e existência, São Paulo: Tempo Brasileiro, 1968.

SOHN-RETHEL. Alfred; Trabalho manual espiritual: para a epistemologia da história ocidental, In: http://ideiaeideologia.com/wpcontent/uploads/2012/10/sohn-rethel-trabalho-manual-e-espiritual.pdf 
V. P. Safatle - Materialismo e Dialéticas sem Aufhebung: Adorno, leitor de Marx; Marx, leitor de Hegel

SCHILLER, Friedrich; A educação estética do homem, São Paulo: Iluminuras, 2011.

REICHELT. Sobre a estrutura lógica do conceito de Capital em Karl Marx, Campinas: Edunicamp, 2013.

\section{Endereço Postal:}

Departamento de Filosofia USP

R. do Lago, 717 - Vila Universitaria, São Paulo - SP - Brasil

Data de recebimento: 02-01-2017

Data de aceite: 14-02-17 